\title{
PENGARUH MOTIVASI BELAJAR, PERSEPSI SISWA TENTANG METODE MENGAJAR GURU, DAN PERHATIAN ORANG TUA TERHADAP PRESTASI BELAJAR AKUNTANSI DASAR SISWA KELAS X AKUNTANSI DAN KEUANGAN LEMBAGA SMK NEGERI 1 WONOSARI TAHUN AJARAN 2018/2019
}

\author{
THE EFFECT OF LEARNING MOTIVATION, STUDENT PERCEPTION ABOUT \\ TEACHERS TEACHING METHOD, AND PARENTS ATTENTION ON BASIC \\ ACCOUNTING LEARNING ACHIEVEMENT STUDENT OF CLASS X ACCOUNTING \\ AND FINANCIAL INSTITUTION OF VOCATIONAL SCHOOL STATE 1 WONOSARI \\ ACADEMIC YEAR 2018/2019
}

\author{
Oleh: \\ Nur Fitria Intan Utari \\ Prodi Pendidikan Akuntansi Universitas Negeri Yogyakarta \\ nurfitintan1@gmail.com \\ Moh. Djazari \\ Staf Pengajar Jurusan Pendidikan Akuntansi Universitas Negeri Yogyakarta
}

\begin{abstract}
Abstrak
Penelitian ini bertujuan untuk mengetahui Pengaruh Motivasi Belajar, Persepsi Siswa tentang Metode Mengajar Guru, dan Perhatian Orang Tua terhadap Prestasi Belajar Akuntansi Dasar Siswa Kelas X AKL SMK Negeri 1 Wonosari Tahun Ajaran 2018/2019, baik secara sendiri-sendiri, maupun secara bersama-sama. Penelitian ini merupakan penelitian ex-post facto dengan pendekatan kuantitatif. Populasi penelitian sebanyak 127 siswa. Pengumpulan data mengunakan metode angket dan metode dokumentasi. Uji prasyarat analisis menggunakan uji linearitas dan uji multikolinearitas. Uji hipotesis yang digunakan adalah analisis regresi sederhana dan analisis regresi ganda tiga prediktor. Hasil dari penelitian ini adalah: (1) Terdapat pengaruh positif Motivasi Belajar terhadap Prestasi Belajar Akuntansi Dasar dibuktikan dengan $r_{x 1 y}=0,348, r_{x 1 y}^{2}=0,114$, dan $t_{\text {hitung }}>t_{\text {tabel }}(4,012>1,657) .(2)$ Terdapat pengaruh positif Persepsi Siswa tentang Metode Mengajar Guru terhadap Prestasi Belajar Akuntansi Dasar dibuktikan dengan $r_{x 2 y}=0,275, r_{x 2 y}^{2}=0,076$ dan $t_{\text {hitung }}>t_{\text {tabel }}(3,204$ $>1,657)$. (3) Terdapat pengaruh positif Perhatian Orang Tua terhadap Prestasi Belajar Akuntansi Dasar dibuktikan dengan $r_{x 3 y}=0,254, r_{x 3 y}^{2}=0,064$, dan $t_{\text {hitung }}>t_{\text {tabel }}(2,301$ $>1,657)$. (4) Terdapat pengaruh positif Motivasi Belajar, Persepsi Siswa tentang Metode Mengajar Guru, dan Perhatian Orang Tua secara bersama-sama terhadap Prestasi Belajar Akuntansi Dasar, yang dibuktikan dengan $R_{y(1,2,3)}=0,391, R_{y(1,2,3)}^{2}=0,153$, dan $F_{\text {hitung }}>F_{\text {tabel }}$ $(7,398>2,678)$. Sumbangan Efektif (SE) menunjukkan total sebesar 15,30\%.
\end{abstract}

Kata kunci: Motivasi Belajar, Persepsi Siswa tentang metode Mengajar Guru, Perhatian Orang Tua, Prestasi Belajar Akuntansi Dasar 


\section{Abstract}

This study aims to determine The Effect of Learning Motivation, Student Perception about Teachers Teaching Method, and Parents individually or together on Basic Accounting Learning Achievements. This study is the Ex-Post Facto with a quantitative approach. The study population was 127 students. Data collection used the questionnaire and documentation methods. Analysis prerequisite test using linearity and multicollinearity test. Hypothesis testing used simple regression analysis for the first, second, and third hypotheses, and multiple regression analysis for the fourth hypothesis. The results of this study show: (1) There is a positive effect of Learning Motivation on Basic Accounting Learning Achievements as evidenced by $r_{x 1 y}=0,348, r_{x y}^{2}=0,114$, and $t_{\text {count }}>t_{\text {table }}(4,012>1,657)$. (2) There is $a$ positive influence Student Perception about Teachers Teaching Method on Basic Accounting Learning Achievement is proven by $r_{x 2 y}=0,275, r_{x 2 y}^{2}=0,076$ and $t_{\text {count }}>t_{\text {table }}(3,204>1,657)$. (3) There is a positive influence of Parents' Attention to Basic Accounting Learning Achievements as evidenced by $r_{x 3 y}=0,254, r_{x 3 y}^{2}=0,064$, and $t_{\text {count }}>t_{\text {table }}(2,301>1,657)$. (4) There is a positive influence of Learning Motivation, Student Perception about Teacher Teaching Methods, and Parents' Attention together on Basic Accounting Learning Achievements which is proven by $R_{y(1,2,3)}=0,391, R_{y(1,2,3)}^{2}=0,153$, and $F_{\text {count }}>F_{\text {table }}$ (7,398>2,678). Effective contribution shows a total of $15.30 \%$.

Keywords: Learning Motivation, Student Perception about Teaching Teacher methods, Parents' Attention, Basic Accounting Learning Achievements.

\section{PENDAHULUAN}

Pendidikan adalah sesuatu yang sangat penting dalam kehidupan setiap manusia. Dalam sebuah proses pendidikan manusia belajar memahami bagaimana menjadi manusia seutuhnya. Pendidikan berkaitan erat dengan belajar, manusia dapat menggali berbagai potensi yang ada dalam dirinya yang kemudian mengimplementasikannya pada kehidupan nyata dengan belajar dari dalam keluarga, masyarakat, maupun lingkungan sekitar.

Belajar menurut Sugihartono (2013:74) merupakan "suatu proses memperoleh pengetahuan dan pengalaman dalam wujud perubahan tingkah laku dan kemampuan bereaksi yang relatif permanen atau menetap karena adanya interaksi individu dengan lingkungannya". "Pembelajaran merupakan perubahan dalam diri seseorang yang berasal dari pengalaman" (Slavin, 2011:177). Berdasarkan pendapat tersebut, maka dapat dikatakan bahwa setiap manusia memiliki kewajiban belajar sepanjang hayatnya baik melalui jalur pendidikan formal, informal maupun nonformal.

Sekolah sebagai sarana pendidikan formal memegang peranan penting dalam pembelajaran. Dengan adanya proses pembelajaran di sekolah, diharapkan adanya perkembangan individu yang lebih optimal. Keberhasilan sekolah dalam mengembangkan individu diharapkan akan melahirkan sumber daya manusia yang berkualitas di kemudian hari. Tolok ukur keberhasilan yang diharapkan oleh sekolah dari pembelajaran yang diberikan oleh sekolah dapat tercermin dari peningkatan prestasi belajar siswa pada tiap bidang keahlian.

Prestasi belajar merupakan suatu hasil yang dicapai siswa dari suatu proses perubahan tingkah laku dari praktik serta pengalaman dalam berinteraksi dengan lingkungannya. Prestasi belajar siswa ini, dapat dipengaruhi berbagai hal baik dari luar maupun dari dalam individu siswa itu sendiri. Slameto (2015:54-72) mengungkapkan berbagai faktor yang dapat memengaruhi prestasi belajar diantaranya: 
1) Faktor Intern, meliputi faktor jasmaniah, faktor psikologis, dan faktor kelelahan.

a) Faktor Jasmaniah, yaitu faktor kesehatan dan cacat tubuh.

b) Faktor Psikologis, yaitu inteligensi, perhatian, minat, bakat, motif, kematangan, dan kesiapan.

c) Faktor Kelelahan, yaitu kelelahan jasmani, dan kelelahan rohani.

2) Faktor Ekstern, meliputi faktor keluarga, faktor sekolah, dan faktor masyarakat.

a) Faktor Keluarga, yaitu cara orang tua mendidik, relasi antaranggota keluarga, suasana rumah, keadaan ekonomi keluarga, pengertian orang tua, dan latar belakang kebudayaan.

b) Faktor sekolah, yaitu metode mengajar, kurikulum, relasi guru dengan murid atau dosen dengan mahasiswa, relasi antarsiswa/ mahasiswa, disiplin sekolah, alat pelajaran, waktu sekolah, standar pelajaran di atas ukuran, keadaan gedung, metode belajar, serta tugas rumah.

c) Faktor Masyarakat, yaitu kegiatan siswa/mahasiswa dalam masyarakat, media masa, teman bergaul, dan bentuk kehidupan masyarakat.

Pembelajaran pada Bidang Keahlian Akuntansi dan Keuangan Lembaga diimplementasikan dalam berbagai mata pelajaran yang disediakan, salah satunya adalah mata pelajaran Akuntansi Dasar. "Akuntansi itu sendiri bertujuan untuk menyajikan informasi ekonomi suatu perusahaan sebagai salah satu dasar pengambilan keputusan perusahaan, pembuatan laporan tersebut didahului dengan adanya proses pencatatan, penggolongan, analisis dan pengendalian transaksi, serta berbagai kegiatan keuangan" (Puspitasari, 2017:4). Akuntansi Dasar merupakan mata pelajaran yang diberikan untuk memelajari hal-hal tersebut dan menjadi mata pelajaran pokok untuk kelas $\mathrm{X}$ bidang keahlian Akuntansi dan Keuangan Lembaga karena sebagai dasar menuju materi pembelajaran mengenai akuntansi selanjutnya, sehingga peningkatan Prestasi Belajar Akuntansi Dasar sangat diharapkan.

Prestasi Belajar Akuntansi Dasar merupakan suatu hasil yang dicapai siswa dari suatu proses perubahan tingkah laku dari praktik serta pengalaman dalam berinteraksi dengan lingkungannya pada mata pelajaran Akuntansi Dasar yang berupa nilai berbentuk angka, huruf maupun kalimat. Prestasi Belajar Akuntansi Dasar ini dapat dipengaruhi berbagai faktor seperti halnya dengan prestasi belajar secara umum. Faktor-faktor tersebut dapat berasal dari luar dan dari dalam diri siswa. Faktor eksternal meliputi faktor keluarga; sekolah yang salah satunya adalah metode mengajar guru; dan masyarakat. Faktor internal meliputi faktor jasmaniah; psikologis salah satunya adalah motivasi; dan kelelahan.

Berdasarkan Keputusan Direktorat Jendral Pendidikan Dasar dan Menengah Kompetensi Keahlian Akuntansi dan Keuangan Lembaga (2017:130) Prestasi Belajar Akuntansi Dasar dapat dilihat dari tercapainya kompetensi dasar pada mata pelajaran Akuntansi Dasar. Penilaian Prestasi Belajar Akuntansi Dasar menurut silabus Akuntansi Dasar tahun 2018 mencakup penilaian pengetahuan dan ketrampilan yang dilakukan dengan adanya tes tertulis dan lisan, penugasan baik individu maupun kelompok berupa pemecahan masalah, observasi dengan lembar penilaian guru untuk menilai sikap dan kinerja siswa, serta adanya portofolio untuk menilai keterampilan siswa. Nilai untuk mengukur Prestasi Belajar Akuntansi Dasar dapat dilihat berdasarkan ulangan harian (UH), ulangan tengah semester (UTS), dan ulangan akhir semester (UAS).

Salah satu faktor yang dapat memengaruhi Prestasi Belajar Akuntansi Dasar seperti yang telah dijelaskan di atas, 
adalah motivasi dalam hal ini Motivasi Belajar. Motivasi menurut Wlowdkowsky (dalam Sugihartono, 2013: 78) merupakan "suatu kondisi yang menyebabkan atau menimbulkan perilaku tertentu dan yang memberi arah ketahanan pada tingkah laku tersebut". Menurut Faryadi (2017:43) mendefinisikan motivasi sebagai "kekuatan intrinsik atau ekstrinsik yang mendorong seseorang, untuk melakukan beberapa tindakan dalam mencapai tujuan yang diinginkan". Berdasarkan pendapat tersebut dapat disimpulkan bahwa Motivasi Belajar adalah suatu dorongan yang berasal dari dalam maupun dari luar diri seseorang untuk memperoleh pengetahuan dan pengalaman dari kegiatan belajar sehingga terjadi suatu perubahan tingkah laku. Motivasi Belajar dapat dilihat dengan adanya semangat siswa untuk berhasil dan meraih cita-cita, dorongan dan kebutuhan untuk belajar, ketertarikan dan perhatian siswa dalam mengikuti pembelajaran serta penjelasan guru di kelas, adanya penghargaan, serta terciptanya lingkungan belajar yang kondusif.

Ketertarikan serta perhatian siswa untuk mengikuti pembelajaran dengan baik tentu tidak semata-mata muncul dari dalam diri siswa saja, namun perlu adanya dukungan dari luar. Guru sebagai pihak yang berinteraksi langsung dengan siswa dalam pembelajaran di sekolah memiliki peran yang penting dalam mengelola kelas. Dalam mengajar, guru dituntut dapat mengelola kelas dengan berbagai metode mengajar yang sesuai dengan pembelajaran yang diberikan, sehingga dapat membangkitkan persepsi-persepsi positif serta ketertarikan siswa dalam mengikuti pembelajaran. Begitu pula dalam pembelajaran Akuntansi Dasar, persepsi positif ini pada akhirnya berdampak pada pencapaian Prestasi Belajar Akuntansi Dasar.

Persepsi Siswa tentang Metode Mengajar Guru adalah proses siswa menerima dan menerjemahkan cara mengajar yang dilakukan oleh guru saat proses belajar mengajar sehingga dapat menciptakan hasil yang optimal. Persepsi Siswa tentang Metode Mengajar Guru dapat berupa persepsi positif dan negatif. Apabila Persepsi Siswa tentang Metode Mengajar Guru negatif akan menimbulkan tindakantindakan negatif pula seperti mengantuk, sulit menerima materi yang diberikan, malas mengerjakan tugas yang diberikan dan halhal lain yang menyebabkan hasil belajar yang kurang optimal. Begitu pula sebaliknya apabila Persepsi Siswa tentang Metode Mengajar Guru positif, maka hal ini akan membuat siswa bersemangat serta mudah dalam mengikuti dan menerima pembelajaran, sehingga akan menciptakan hasil berupa Prestasi Belajar Akuntansi Dasar yang optimal.

Faktor eksternal lain yang dapat memengaruhi Prestasi Belajar Akuntansi Dasar adalah keluarga atau lebih khususnya Perhatian Orang Tua. Perhatian dapat diartikan sebagai "kegiatan yang dilakukan seseorang dengan pemilihan rangsangan yang datang dari lingkungannya, seseorang yang telah memilih rangsangan tentu akan tertuju dan terfokus pada rangsangan yang diterima tersebut" (Slameto, 2015:105). Jadi, dapat disimpulkan bahwa Perhatian Orang Tua merupakan suatu pemusatan kegiatan orang tua yang berfokus atau tertuju pada anak sebagai rangsangan yang dipilihnya dalam hal ini adalah aktivitas belajar anak. Menurut Dwi Siswoyo (2013:136) "keluarga merupakan pusat pendidikan yang pertama dan utama karena dalam keluarga itulah kepribadian anak terbentuk". Orang tua memiliki pengaruh dan tanggung jawab yang paling besar dalam pendidikan alami anak, karena dari orang tua lah anak pertama kali mendapat pendidikan atau sebagai jalur pendidikan informal anak. Dengan menciptakan interaksi, komunikasi serta yang terpenting adalah perhatian yang baik pada anak orang tua akan memotivasi perkembangan kepribadian anaknya. Perhatian Orang Tua dapat berupa pemberian fasilitas belajar yang baik, dukungan atau motivasi orang tua terhadap 
proses belajar anak, serta menciptakan suasana belajar yang kondusif.

SMK Negeri 1 Wonosari merupakan salah satu Sekolah Menengah Kejuruan yang membuka bidang keahlian Akuntansi dan Keuangan Lembaga, dengan kuota empat kelas setiap angkatannya dan terdiri dari 32 siswa tiap kelasnya. Masalah yang ditemukan dari observasi yang dilakukan peneliti pada bulan November 2018 di Kelas X Bidang keahlian Akuntansi dan Keuangan Lembaga SMK Negeri 1 Wonosari, dalam pembelajaran mata pelajaran Akuntansi Dasar masih ada beberapa siswa yang kurang aktif dan antusias dalam mengikuti pembelajaran di kelas, serta masih terdapat guru yang mengajar dengan metode kurang variatif, seperti hanya ceramah dan pembahasan soal bersama, selain itu, banyak siswa berasal dari daerah yang cukup jauh dari sekolah sehingga memilih untuk tinggal di rumah kos, hal ini tentu membuat siswa jauh dari orang tua. Beberapa hal-hal tersebut kemungkinan dapat berpengaruh terhadap capaian prestasi belajar siswa tersebut khususnya pada mata pelajaran Akuntansi Dasar di mana berdasarkan hasil ulangan harian pertama yang telah dilaksanakan, sebanyak 36\% atau 46 siswa dari 127 siswa masih mendapatkan nilai di bawah Kriteria Ketuntasan Minimal (KKM) yaitu 75 , dan $32 \%$ siswa masih dengan nilai kurang maksimal yaitu mendapatkan nilai antara 75-79.

Berdasarkan latar belakang tersebut, peneliti tertarik untuk melakukan penelitian dengan judul "Pengaruh Motivasi Belajar, Persepsi Siswa tentang Metode Mengajar Guru, dan Perhatian Orang Tua terhadap Prestasi Belajar Akuntansi Dasar Siswa Kelas X Akuntansi dan Keuangan Lembaga SMK Negeri 1 Wonosari Tahun Ajaran 2018/2019”.

\section{METODE PENELITIAN Jenis Penelitian}

Jenis penelitian ini adalah penelitian kausal komparatif dengan ex post facto atau penelitian yang dilakukan sesuai kenyataan yang ada dan tanpa adanya manipulasi, di mana peneliti berusaha menemukan pengaruh (sebab-akibat) dari suatu kejadian. Pendekatan yang digunakan dalam penelitian ini adalah pendekatan kuantitatif.

\section{Waktu dan Tempat Penelitian}

Penelitian ini dilaksanakan di Kelas X Bidang Keahlian Akuntansi SMK Negeri 1 Wonosari Tahun Ajaran 2018/2019. Waktu penelitian yaitu pada bulan Februari - Maret 2019.

\section{Populasi Penelitian}

Penelitian ini merupakan penelitian populasi. Populasi pada penelitian ini adalah seluruh Siswa Kelas X Akuntansi dan Keuangan Lembaga SMK Negeri 1 Wonosari Tahun Ajaran 2018/2019 yang berjumlah 127 siswa dan terbagi ke dalam empat kelas.

\section{Teknik Pengumpulan Data}

Penelitian ini menggunakan teknik pengumpulan data berupa kuesioner/angket dan dokumentasi. Kuisioner/angket digunakan untuk mengumpulkan data tentang Motivasi Belajar Siswa, Persepsi Siswa tentang Metode Mengajar Guru, dan Perhatian Orang Tua, sedangkan dokumentasi untuk mengumpulkan data tentang Prestasi Belajar Akuntansi Dasar Siswa Kelas X SMK Negeri 1 Wonosari Tahun Ajaran 2018/2019.

\section{Instrumen Penelitian}

Instrumen yang digunakan dalam penelitian ini adalah dokumen dan angket. Pada instrumen berupa angket, penyekoran alternatif jawaban pada setiap butir pernyataan dalam angket menggunakan skala Linkert yang di modifikasi, dan menggunakan alternatif jawaban Selalu (SL), Sering (SR), Kadang-kadang (KK), dan Tidak Pernah (TP) dengan skor pernyataan positif dan negatif. Uji coba instrumen angket menggunakan uji coba terpakai, pengujian dilakukan dengan mengambil sebagian dari calon subjek penelitian, subjek tersebut dijadikan subjek 
uji coba dan sekaligus subjek penelitian (Suharsimi, 2016:161), dengan 30 siswa sebagai subyek uji coba instrumen. Pengujian dilakukan dengan menguji validitas dan reliabilitas instrumen.

\section{Teknik Analisis Data}

Sebelum melakukan analisis data, terlebih dahulu dilakukan uji prasyarat analisis yaitu uji linearitas dan uji multikolinearitas, apabila telah memenuhi uji prasyarat analisis, maka penelitian dapat dilanjutkan dengan melakukan analisis data dan pengujian hipotesis. Teknik analisis data yang digunakan dalam penelitian ini adalah analisis regresi sederhana dan analisis regresi ganda tiga prediktor, serta menghitung sumbangan relatif dan sumbangan efektif

\section{HASIL PENELITIAN DAN PEMBA- HASAN}

\section{Deskripsi Data}

a. Prestasi Belajar Akuntansi Dasar

Prestasi Belajar Akuntansi Dasar diperoleh dari nilai Ujian Tengah Semester dan nilai Ujian Akhir Semester sebelum perbaikan siswa kelas $\mathrm{X}$ Akuntansi dan Keuangan Lembaga tahun ajaran 2018/2019. Berdasarkan data yang diperoleh kemudian dianalisis dan didapatkan hasil berupa nilai mean 79,78 , nilai median sebesar 80 , nilai modus adalah 78 dan nilai standar deviasi adalah 6,05. Berdasarkan perhitungan yang dilakukan dapat diperoleh tabel distribusi frekuensi sebagai berikut:
Tabel 1. Distribusi Frekuensi Variabel Prestasi Belajar Akuntansi Dasar

\begin{tabular}{|c|c|c|c|}
\hline No. & Interval & Frekuensi & \% \\
\hline 1 & $66-69$ & 5 & 3,937 \\
\hline 2 & $70-73$ & 17 & 13,386 \\
\hline 3 & $74-77$ & 20 & 15,748 \\
\hline 4 & $78-81$ & 31 & 24,409 \\
\hline 5 & $82-85$ & 30 & 23,622 \\
\hline 6 & $86-89$ & 19 & 14,961 \\
\hline 7 & $90-93$ & 5 & 3,937 \\
\hline & Jumlah & 127 & 100 \\
\hline
\end{tabular}

Kategori kecenderungan atau tinggi rendahnya Prestasi Belajar Akuntansi Dasar dapat diidentifikasi melalui nilai Kriteria Ketuntasan Minimal (KKM), di mana nilai KKM yang digunakan oleh sekolah adalah 75. Klasifikasi kecenderungan varibel Prestasi Belajar Akuntansi Dasar dapat diringkas dalam tabel sebagai berikut:

Tabel 2. Kategori Kecenderungan Variabel Prestasi Belajar Akuntansi Dasar

\begin{tabular}{|c|c|c|c|c|}
\hline \multirow{2}{*}{ No. } & \multirow{2}{*}{$\begin{array}{c}\text { Kate } \\
\text {-gori }\end{array}$} & $\begin{array}{c}\text { Abso } \\
\text { lut }\end{array}$ & $\begin{array}{c}\text { Rela- } \\
\text { tif } \\
(\boldsymbol{\%})\end{array}$ & \multirow{2}{*}{ Ket. } \\
\hline 1. & $\geq 75$ & 99 & 77,95 & Tuntas \\
\hline 2. & $<75$ & 28 & 22,05 & $\begin{array}{c}\text { Tidak } \\
\text { Tuntas }\end{array}$ \\
\hline & Total & 127 & 100 & \\
\hline
\end{tabular}

b. Motivasi Belajar

Motivasi Belajar diperoleh dari angket penelitian yang terdiri dari 20 pernyataan yang diisi oleh 127 responden. Terdapat 4 alternatif jawaban di mana skor tertinggi adalah 4 dan skor terendah adalah 1. Berdasarkan data yang diperoleh kemudian dianalisis dan didapatkan hasil berupa nilai mean 59,40 , nilai median sebesar 59, nilai modus adalah 59 dan nilai standar deviasi adalah 7,35. Berdasarkan perhitungan yang dilakukan diperoleh 
tabel distribusi frekuensi sebagai berikut:

Tabel 3. Distribusi frekuensi Variabel Motivasi Belajar

\begin{tabular}{|c|c|c|c|}
\hline No. & Interval & Frekuensi & $\mathbf{\%}$ \\
\hline 1 & $40-45$ & 4 & 3,150 \\
\hline 2 & $46-51$ & 11 & 8,661 \\
\hline 3 & $52-57$ & 36 & 28,346 \\
\hline 4 & $58-63$ & 35 & 27,559 \\
\hline 5 & $64-69$ & 31 & 24,409 \\
\hline 6 & $70-75$ & 9 & 7,087 \\
\hline 7 & $76-81$ & 1 & 0,787 \\
\hline & Jumlah & 127 & 100 \\
\hline
\end{tabular}

Kategori kecenderungan variabel Motivasi Belajar menggunakan kriteria skor ideal. Selanjutnya variabel Motivasi Belajar digolongkan ke dalam tiga kategori kecenderungan, seperti pada tabel berikut:

Tabel 4. Kategori Kecenderungan Variabel Motivasi Belajar

\begin{tabular}{|c|c|c|c|c|}
\hline \multirow{2}{*}{$\begin{array}{c}\text { No } \\
\cdot\end{array}$} & $\begin{array}{c}\text { Kate- } \\
\text { gori }\end{array}$ & $\begin{array}{c}\text { Abso } \\
\text {-lut }\end{array}$ & $\begin{array}{c}\text { Rela- } \\
\text { tif } \\
(\%)\end{array}$ & \multirow{2}{*}{ Ket. } \\
\hline 1. & $\mathrm{X}>51$ & 68 & 53,54 & Tinggi \\
\hline 2. & $\begin{array}{c}34- \\
51\end{array}$ & 58 & 45,67 & Sedang \\
\hline 3. & $\mathrm{X}<34$ & 1 & 0,79 & Rendah \\
\hline & Total & 127 & 100 & \\
\hline
\end{tabular}

c. Persepsi Siswa tentang Metode Mengajar Guru

Persepsi Siswa tentang Metode Mengajar Guru diperoleh dari angket penelitian yang terdiri dari 17 pernyataan yang diisi oleh 127 responden. Terdapat 4 alternatif jawaban di mana skor tertinggi adalah 4 dan skor terendah adalah 1. Berdasarkan data yang diperoleh kemudian dianalisis dan didapatkan hasil berupa nilai mean 51,83, nilai median sebesar 53, nilai modus adalah 46 dan nilai standar deviasi adalah 7,95. Berdasarkan perhitungan yang dilakukan diperoleh tabel distribusi frekuensi sebagai berikut:

Tabel 5. Distribusi Frekuensi Persepsi Siswa tentang Metode mengajar Guru

\begin{tabular}{|c|c|c|c|}
\hline No. & Interval & Frekuensi & \% \\
\hline 1 & $30-33$ & 2 & 1,575 \\
\hline 2 & $34-37$ & 13 & 10,236 \\
\hline 3 & $38-41$ & 14 & 11,024 \\
\hline 4 & $42-45$ & 24 & 18,898 \\
\hline 5 & $46-49$ & 26 & 20,472 \\
\hline 6 & $50-53$ & 42 & 33,071 \\
\hline 7 & $54-57$ & 6 & 4,724 \\
\hline & Jumlah & 127 & 100 \\
\hline
\end{tabular}

ategori kecenderungan variabel Persepsi Siswa tentang Metode Mengajar Guru menggunakan kriteria skor ideal. Selanjutnya variabel Persepsi Siswa tentang Metode Mengajar Guru digolongkan ke dalam 3 kategori kecenderungan, seperti pada tabel berikut:

Tabel 6. Kategori Kecenderungan Variabel Persepsi Siswa tentang Metode Mengajar Guru

\begin{tabular}{|c|c|c|c|c|}
\hline \multirow[b]{2}{*}{ No. } & \multirow[b]{2}{*}{ Kategori } & \multicolumn{2}{|c|}{ Frekuensi } & \multirow[b]{2}{*}{ Ket. } \\
\hline & & $\begin{array}{c}\text { Abso- } \\
\text { lut }\end{array}$ & $\begin{array}{c}\text { Relatif } \\
(\%)\end{array}$ & \\
\hline 1. & $X>60$ & 52 & 40,95 & Tinggi \\
\hline 2. & $40-60$ & 75 & 59,05 & Sedang \\
\hline 3. & $X<40$ & 0 & 0 & Rendah \\
\hline & Total & 127 & 100 & \\
\hline
\end{tabular}

d. Perhatian Orang Tua

Perhatian Orang Tua diperoleh dari angket penelitian yang terdiri dari 14 pernyataan yang diisi oleh 127 responden. Terdapat 4 alternatif jawaban di mana skor tertinggi adalah 4 dan skor terendah adalah 1. Berdasarkan 
data yang diperoleh kemudian dianalisis dan didapatkan hasil berupa nilai mean 45,95, nilai median sebesar 47, nilai modus adalah 51 dan nilai standar deviasi adalah 5,75. Berdasarkan perhitungan yang dilakukan diperoleh tabel distribusi frekuensi sebagai berikut:

Tabel 7. Distribusi Frekuensi Variabel Perhatian Orang Tua

\begin{tabular}{|c|c|c|c|}
\hline No. & Interval & Frekuensi & \% \\
\hline 1 & $33-37$ & 1 & 0,787 \\
\hline 2 & $38-42$ & 19 & 14,961 \\
\hline 3 & $43-47$ & 26 & 20,472 \\
\hline 4 & $48-52$ & 14 & 11,024 \\
\hline 5 & $53-57$ & 30 & 23,622 \\
\hline 6 & $58-62$ & 26 & 20,472 \\
\hline 7 & $63-67$ & 10 & 7,874 \\
\hline 8 & $68-72$ & 1 & 0,787 \\
\hline & Jumlah & 127 & 100 \\
\hline
\end{tabular}

Kategori kecenderungan variabel Perhatian Orang Tua menggunakan kriteria skor ideal. Selanjutnya variabel Perhatian Orang Tua digolongkan ke dalam 3 kategori kecenderungan, seperti pada tabel berikut:

Tabel 8. Kategori Kecenderungan Variabel Perhatian Orang Tua

\begin{tabular}{|c|c|c|c|c|}
\hline No & Kate- \\
\cline { 3 - 5 } & gori & $\begin{array}{c}\text { Abso- } \\
\text { lut }\end{array}$ & $\begin{array}{c}\text { Rekla- } \\
\text { tif } \\
(\%)\end{array}$ & \\
\hline 1. & $\begin{array}{c}\mathrm{X}> \\
42\end{array}$ & 98 & 77,17 & Tinggi \\
\hline 2. & $\begin{array}{c}28- \\
42\end{array}$ & 29 & 22,83 & Sedang \\
\hline 3. & $\begin{array}{c}\mathrm{X}< \\
28\end{array}$ & 0 & 0,00 & Rendah \\
\hline & Total & 127 & 100 & \\
\hline
\end{tabular}

Uji Prasyarat Analisis

a. Uji Linearitas

Tabel 9. Rangkuman Hasil Uji Linearitas

\begin{tabular}{|l|c|c|c|c|}
\hline \multirow{2}{*}{$\begin{array}{c}\text { Var. } \\
\text { Be- } \\
\text { bas }\end{array}$} & \multicolumn{2}{|c|}{ Harga F } & Sig. & $\begin{array}{l}\text { Kesim- } \\
\text { pulan }\end{array}$ \\
\cline { 2 - 5 } & Hitung & Tabel & & \\
\hline$X_{1}$ & 1,503 & 1,580 & 0,071 & Linear \\
\hline $\mathrm{X} 2$ & 1,549 & 1,586 & 0,059 & Linear \\
\hline $\mathrm{X} 3$ & 0,842 & 1,647 & 0,668 & Linear \\
\hline
\end{tabular}

Berdasarkan Tabel 9 dapat dilihat bahwa pada taraf kesalahan 5\% nilai Fhitung pada setiap variabel lebih kecil dari $F_{\text {tabel }}$ dan nilai Sig. pada masing masing variabel lebih besar dari 0,05, sehingga dapat diambil kesimpulan bahwa masing-masing variabel bebas memiliki hubungan yang linear dengan variabel terikat.

b. Uji Multikolinearitas

Tabel 10. Rangkuman Hasil Uji Multikolinearitas

\begin{tabular}{|c|c|c|c|c|}
\hline $\begin{array}{c}\text { Varia } \\
\text {-bel }\end{array}$ & $\mathbf{X}_{1}$ & $\mathbf{X}_{2}$ & $\mathbf{X}_{3}$ & $\begin{array}{c}\text { Kesim- } \\
\text { pulan }\end{array}$ \\
\hline $\mathrm{X}_{1}$ & 1 & 0,592 & $\begin{array}{c}0,20 \\
1\end{array}$ & \multirow{3}{*}{$\begin{array}{c}\text { Tidak } \\
\text { Terjadi } \\
\text { Multiko- } \\
\text { linearitas }\end{array}$} \\
\hline$X_{2}$ & 0,592 & 1 & $\begin{array}{c}0,29 \\
1 \\
\end{array}$ & \\
\hline$X_{3}$ & 0,201 & 0,291 & 1 & \\
\hline
\end{tabular}

Berdasarkan Tabel 10 terlihat bahwa koefisien korelasi setiap variabel bebas dengan variabel bebas yang lain kurang dari 0,60, uji ini dikatakan terjadi multikolinieritas apabila koefisien korelasi antarvariabel (r) $>0,60$ dan dikatakan tidak terjadi multikolineraritas apabila $\mathrm{r} \leq 0,60$ (Sunyoto, 2011:79), sehingga dapat disimpulkan bahwa tidak terjadi multikolinearitas antar variabel bebas. 
Uji Hipotesis Penelitian

a. Uji Hipotesis Pertama

Tabel 11. Hasil Pengujian Hipotesis Pertama

\begin{tabular}{|c|c|c|c|c|c|}
\hline Kons. & Koe. & $\mathbf{r}_{\mathbf{x} 1 \mathbf{y}}$ & $\mathbf{r}_{\mathbf{x} 1 \mathbf{y}}$ & $\begin{array}{c}\mathbf{t} \\
\text { hitung }\end{array}$ & $\mathbf{t}_{\text {tabel }}$ \\
\hline 63,29 & 0,27 & 0,34 & 0,11 & 4,01 & 1,65 \\
3 & 8 & 8 & 4 & 2 & 7 \\
\hline
\end{tabular}

Tabel 11 menunjukkan bahwa koefisien korelasi antara $\mathrm{X}_{1}$ dan $\mathrm{Y}\left(\mathrm{r}_{\mathrm{x} 1 \mathrm{y}}\right)$ bernilai positif yaitu sebesar 0,348 . Hasil tersebut membuktikan bahwa variabel Motivasi Belajar mempunyai pengaruh positif terhadap Prestasi Belajar Akuntansi Dasar Siswa Kelas X Akuntansi dan Keuangan Lembaga SMK Negeri 1 Wonosari Tahun Ajaran 2018/2019, dengan koefisien determinasi variabel Motivasi Belajar $\left(\mathrm{r}^{2}{ }_{\mathrm{x} 1 \mathrm{y}}\right)$ sebesar 0,114 atau memberi pengaruh sebesar $11,4 \%$.

Berdasarkan Tabel 11 diperoleh koefisien Motivasi Belajar $\left(\mathrm{X}_{1}\right)$ sebesar 0,278, dan bilangan konstanta sebesar 63,293 . Dari hasil tersebut dapat dibuat persamaan regresi sebagai berikut:

$$
\mathrm{Y}=0,278 \mathrm{X}_{1}+63,293
$$

Persamaan tersebut menunjukkan koefisien Motivasi Belajar $\left(\mathrm{X}_{1}\right)$ sebesar 0,278 yang berarti jika Motivasi Belajar $\left(\mathrm{X}_{1}\right)$ meningkat 1 satuan, maka Prestasi Belajar Akuntansi Dasar (Y) akan meningkat sebesar 0,278. Berdasarkan Tabel 11 juga dapat dilihat harga thitung dan $t_{\text {tabel }}$ yang kemudian dibandingkan, kriteria yang digunakan adalah apabila $t_{\text {hitung }}$ lebih besar dari $t_{\text {tabel }}$ maka hipotesis diterima atau dengan kata lain variabel bebas $(\mathrm{X})$ memberikan pengaruh positif terhadap variabel terikat (Y). Dari perbandingan yang dilakukan didapatkan hasil bahwa thitung lebih besar dari $t_{\text {tabel }}$ $(4,012>1,657)$, sehingga hipotesis diterima atau terdapat pengaruh positif Motivasi Belajar terhadap Prestasi Belajar Akuntansi Dasar Siswa Kelas X
Akuntansi dan Keuangan Lembaga SMK Negeri 1 Wonosari Tahun Ajaran 2018/2019.

Hasil penelitian ini sesuai dengan pendapat yang diungkapkan oleh Slameto (2015:54-72) bahwa faktor yang dapat memengaruhi belajar dapat berasal dari dalam individu itu sendiri salah satunya adalah motif. Sardiman (2011:85) juga telah mengungkapkan bahwa motivasi dapat berfungsi sebagai pendorong usaha dan pencapaian prestasi, intensitas motivasi seorang siswa akan sangat menentukan tingkat pencapaian prestasi belajarnya. Begitu pula dengan Prestasi Belajar Akuntansi Dasar juga dipengaruhi oleh Motivasi Belajar masing masing siswa, seperti yang telah dibuktikan dalam penelitian ini bahwa Motivasi Belajar memberikan pengaruh positif terhadap Prestasi Belajar Akuntansi Dasar Siswa Kelas X Akuntansi dan Keuangan Lembaga SMK Negeri 1 Wonosari Tahun Ajaran 2018/2019. Penelitian ini didukung oleh penelitian yang dilakukan sebelumnya oleh Afrial Irfa' (2017), dengan judul "Pengaruh Motivasi Belajar, Kreativitas Belajar, dan Lingkungan Teman Sebaya terhadap Prestasi Belajar Akuntansi Keuangan Siswa Kelas XI Akuntansi SMK Negeri 1 Tempel Tahun Ajaran 2016/2017”, yang menunjukkan hasil bahwa Motivasi Belajar berpengaruh positif terhadap Prestasi Belajar Akuntansi Keuangan yang ditunjukkan dengan nilai $\mathrm{r}_{\mathrm{x} 1 \mathrm{y}}=$ 0,$424 ; r^{2}{ }_{x 1 y}=0,180$.

b. Uji Hipotesis Kedua

Tabel 12. Hasil Pengujian Hipotesis Kedua

\begin{tabular}{|c|c|c|c|c|c|}
\hline Kons. & Koef. & $\mathbf{r}_{\mathbf{x} 2 \mathbf{y}}$ & $\mathbf{r}_{\mathbf{x} 2 \mathbf{y}}$ & $\mathbf{t}_{\text {hitung }}$ & $\mathbf{t}_{\text {tabel }}$ \\
\hline 68,938 & 0,209 & 0,275 & 0,076 & 3,024 & 1,657 \\
\hline
\end{tabular}

Tabel 12 menunjukkan bahwa koefisien korelasi antara $\mathrm{X}_{2}$ dan $\mathrm{Y}\left(\mathrm{r}_{\mathrm{x} 2 \mathrm{y}}\right)$ bernilai positif yaitu sebesar 0,275. Hasil tersebut membuktikan bahwa 
variabel Persepsi Siswa tentang Metode Mengajar Guru mempunyai pengaruh positif terhadap Prestasi Belajar Akuntansi Dasar Siswa Kelas X Akuntansi dan Keuangan Lembaga SMK Negeri 1 Wonosari Tahun Ajaran 2018/2019, dengan nilai koefisien determinasi variabel Persepsi Siswa tentang Metode Mengajar Guru $\left(\mathrm{r}^{2}{ }_{\mathrm{x} 2 \mathrm{y}}\right)$ sebesar 0,076 atau memberi pengaruh sebesar 7,6 \%. Berdasarkan Tabel 12 diperoleh koefisien Persepsi Siswa tentang Metode Mengajar Guru $\left(\mathrm{X}_{2}\right)$ sebesar 0,209, dan bilangan konstanta sebesar 68,938. Dari hasil tersebut dapat dibuat persamaan regresi sebagai berikut:

$$
Y=0,209 X_{1}+68,938
$$

Persamaan tersebut menunjukkan koefisien Persepsi Siswa tentang Metode Mengajar Guru ( $\left.\mathrm{X}_{2}\right)$ sebesar 0,209 yang berarti jika Persepsi Siswa tentang Metode Mengajar Guru $\left(\mathrm{X}_{2}\right)$ meningkat 1 satuan, maka Prestasi Belajar Akuntansi Dasar (Y) akan meningkat sebesar 0,209. Berdasarkan Tabel 12 juga dapat dilihat harga $t_{\text {hitung }}$ dan $t_{\text {tabel }}$ yang kemudian dibandingkan, kriteria yang digunakan adalah apabila

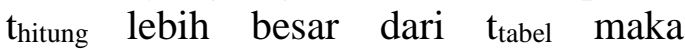
hipotesis diterima atau dengan kata lain variabel bebas (X) memberikan pengaruh positif terhadap variabel terikat (Y). Dari perbandingan yang dilakukan, didapatkan hasil bahwa thitung lebih besar dari $t_{\text {tabel }}(3,204>1,657)$, sehingga hipotesis diterima, atau terdapat pengaruh positif Persepsi Siswa tentang Metode Mengajar Guru terhadap Prestasi Belajar Akuntansi Dasar Siswa Kelas X Akuntansi dan Keuangan Lembaga SMK Negeri 1 Wonosari Tahun Ajaran 2018/2019.

Hasil penelitian ini sesuai dengan pendapat Surya (2015:205-206) bahwa guru perlu menciptakan persepsi siswa secara proporsional dan memadai melalui perilaku mengajar yang tepat, sehingga menciptakan hasil perilaku pembelajaran yang meliputi aspek kognitif, afektif dan psikomotor secara efektif pula. Hasil penelitian ini didukung oleh hasil dari penelitian sebelumnya yang dilakukan oleh Sari Rumanti Palupi (2017), dengan judul "Pengaruh Kemandirian Belajar, Persepsi Siswa tentang Metode Mengajar Guru dan Perhatian Orang Tua terhadap Prestasi Belajar Akuntansi Siswa Kelas XI IPS SMA Negeri 1 Srandakan Tahun Ajaran 2016/2017", yang menunjukkan hasil bahwa terdapat pengaruh positif Persepsi Siswa tentang Metode Mengajar Guru terhadap Prestasi Belajar Akuntansi Siswa Kelas XI IPS SMA Negeri 1 Srandakan Tahun Ajaran 2016/2017 dibuktikan dengan $r_{x 2 y} 0,323$ dan $r_{x 2 y}^{2} 0,104$.

c. Uji Hipotesis Ketiga

Tabel 13. Hasil Pengujian Hipotesis Ketiga

\begin{tabular}{|c|c|c|c|c|c|}
\hline Kons. & $\begin{array}{c}\text { Koef } \\
\cdot\end{array}$ & $\mathbf{r}_{\mathbf{x} 3 \mathbf{y}}$ & $\mathbf{r}^{\mathbf{2}} \mathbf{x} \mathbf{y}$ & $\begin{array}{c}\text { thitun } \\
\mathbf{g}\end{array}$ & $\mathbf{t}$ tabel \\
\hline 67,54 & 0,26 & 0,25 & 0,06 & 2,93 & 1,65 \\
9 & 7 & 4 & 4 & 1 & 7 \\
\hline
\end{tabular}

Tabel 13 menunjukkan bahwa

koefisien korelasi antara $\mathrm{X}_{3}$ dan $\mathrm{Y}\left(\mathrm{r}_{\mathrm{x} 3 \mathrm{y}}\right)$ bernilai positif yaitu sebesar 0,254. Hasil tersebut membuktikan bahwa variabel Perhatian Orang Tua mempunyai pengaruh positif terhadap Prestasi Belajar Akuntansi Dasar Siswa Kelas X Akuntansi dan Keuangan Lembaga SMK Negeri 1 Wonosari Tahun Ajaran 2018/2019, dengan nilai koefisien determinasi variabel Perhatian Orang Tua $\left(\mathrm{r}_{\mathrm{x} 3 \mathrm{y}}^{2}\right)$ sebesar 0,064 atau memberikan pengaruh sebesar 6,4\%. Berdasarkan Tabel 13 diperoleh koefisien Perhatian Orang Tua $\left(\mathrm{X}_{3}\right)$ sebesar 0,267, dan bilangan konstanta sebesar 67,549. Dari hasil tersebut dapat dibuat persamaan regresi sebagai berikut: 


$$
Y=0,267 X_{1}+67,549
$$

Persamaan tersebut menunjukkan koefisien Perhatian Orang Tua $\left(\mathrm{X}_{3}\right)$ sebesar 0,267 yang berarti jika Perhatian Orang Tua $\left(\mathrm{X}_{3}\right)$ meningkat 1 satuan, maka Prestasi Belajar Akuntansi Dasar (Y) akan meningkat sebesar 0,267. Berdasarkan Tabel 13 diperoleh juga harga $t_{\text {hitung }}$ dan $t_{\text {tabel }}$ yang kemudian dibandingkan. Kriteria yang digunakan adalah apabila $t_{\text {hitung }}$ lebih besar dari $t_{\text {tabel }}$ maka hipotesis diterima atau dengan kata lain variabel bebas (X) memberikan pengaruh positif terhadap variabel terikat (Y). Dari perbandingan yang dilakukan, didapatkan hasil bahwa $t_{\text {hitung }}$ lebih besar dari $t_{\text {tabel }}(2,031>$ 1,657), sehingga hipotesis diterima, atau pengaruh positif Perhatian Orang Tua terhadap Prestasi Belajar Akuntansi Dasar Siswa Kelas X Akuntansi dan Keuangan Lembaga SMK Negeri 1 Wonosari Tahun Ajaran 2018/2019.
Hasil penelitian ini sesuai dengan pendapat Slameto (2015:54-72) bahwa salah satu faktor eksternal yang dapat memengaruhi belajar adalah orang tua. Diperkuat juga oleh Khodijah (2014:60) bahwa pola asuh orang tua, fasilitas belajar yang disediakan, perhatian, dan motivasi merupakan dukungan belajar yang harus diberikan orang tua untuk kesuksesan belajar anak. Hasil penelitian ini didukung oleh hasil penelitian yang telah dilakukan sebelumnya oleh Mia Rizky Fausi (2017), dengan judul Pengaruh Perhatian Orang Tua, Disiplin Belajar, dan Motivasi Belajar terhadap Prestasi Belajar Akuntansi Siswa Kelas XI IPS SMA Negeri 1 Depok Tahun Ajaran 2016/2017, hasil penelitian ini menunjukkan bahwa terdapat pengaruh positif Perhatian Orang Tua terhadap Prestasi Belajar Akuntansi dengan $r_{x 1 y}$ $=0,566, r_{x 1 y}^{2}=0,321$.

Tabel 14. Hasil Pengujian Hipotesis Keempat

\begin{tabular}{|c|c|c|c|c|c|c|}
\hline Var. & Konst. & Koef. & $\begin{array}{c}\mathrm{R}_{\mathbf{y}} \\
(1,2,3)\end{array}$ & $\begin{array}{c}\mathrm{R}_{\mathrm{y}}^{2} \\
(1,2,3)\end{array}$ & $\begin{array}{l}F_{\text {hit- }} \\
\text { ung }\end{array}$ & $\begin{array}{l}\mathrm{F}_{\mathrm{ta}-} \\
\text { bel }\end{array}$ \\
\hline $\mathrm{X}_{1}$ & \multirow{3}{*}{55,608} & 0,214 & \multirow{3}{*}{0,391} & \multirow{3}{*}{0,153} & \multirow{3}{*}{7,398} & \multirow{3}{*}{2,678} \\
\hline$X_{2}$ & & 0,052 & & & & \\
\hline$X_{3}$ & & 0,190 & & & & \\
\hline
\end{tabular}

a. Uji Hipotesis Keempat

Tabel 14 menunjukkan bahwa koefisien korelasi antara $\mathrm{X}_{1}, \mathrm{X}_{2}$, dan $\mathrm{X}_{3}$ secara bersama-sama terhadap $\mathrm{Y}\left(\mathrm{r}_{\mathrm{x} 3 \mathrm{y}}\right)$ bernilai positif yaitu sebesar 0,391. Hasil tersebut membuktikan bahwa variabel Motivasi Belajar $\left(\mathrm{X}_{1}\right)$, Persepsi Siswa tentang Metode Mengajar Guru $\left(\mathrm{X}_{2}\right)$, dan Perhatian Orang Tua $\left(\mathrm{X}_{3}\right)$ secara bersama-sama mempunyai pengaruh positif terhadap Prestasi Belajar Akuntansi Dasar Siswa Kelas X Akuntansi dan Keuangan Lembaga SMK Negeri 1 Wonosari Tahun Ajaran 2018/2019, dengan nilai koefisien determinasi sebesar 0,153 atau ketiga variabel tersebut secara bersama-sama memberikan pengaruh sebesar $15,3 \%$. Berdasarkan Tabel 14 diperoleh koefisien Motivasi Belajar $\left(\mathrm{X}_{1}\right)$ sebesar 0,214, Persepsi Siswa tentang Metode Mengajar Guru $\left(\mathrm{X}_{2}\right)$ sebesar 0,052, Perhatian Orang Tua $\left(\mathrm{X}_{3}\right)$ sebesar 0,190, dan bilangan konstanta sebesar 55,608. Dari hasil tersebut dapat dibuat persamaan regresi sebagai berikut:

$$
\begin{aligned}
\mathrm{Y}= & 0,214 \mathrm{X}_{1}+0,052 \mathrm{X}_{2}+0,190 \mathrm{X}_{3}+ \\
& 67,549
\end{aligned}
$$

Persamaan di atas menunjukkan bahwa:

1) Nilai koefisien Motivasi Belajar $\left(X_{1}\right)$ sebesar 0,214 yang berarti jika Motivasi Belajar $\left(\mathrm{X}_{1}\right)$ meningkat 1 
satuan, sedangkan Persepsi Siswa tentang Metode Mengajar Guru ( $\left.\mathrm{X}_{2}\right)$, dan Perhatian Orang Tua $\left(\mathrm{X}_{3}\right)$ tetap, maka Prestasi Belajar Akuntansi Dasar (Y) akan meningkat sebesar 0,214 .

2) Nilai koefisien Persepsi Siswa tentang Metode Mengajar Guru $\left(\mathrm{X}_{2}\right)$ sebesar 0,052 yang berarti jika Persepsi Siswa tentang Metode Mengajar Guru $\left(\mathrm{X}_{2}\right)$ meningkat 1 satuan, sedangkan Motivasi Belajar $\left(\mathrm{X}_{1}\right)$, dan Perhatian Orang Tua $\left(\mathrm{X}_{3}\right)$ tetap, maka Prestasi Belajar Akuntansi Dasar (Y) akan meningkat sebesar 0,052.

3) Nilai koefisien Perhatian Orang Tua $\left(\mathrm{X}_{3}\right)$ sebesar 0,190 yang berarti jika Perhatian Orang Tua $\left(\mathrm{X}_{3}\right)$ meningkat 1 satuan, sedangkan Motivasi Belajar $\left(\mathrm{X}_{1}\right)$, dan Persepsi Siswa tentang Metode Mengajar Guru $\left(\mathrm{X}_{2}\right)$ tetap, maka Prestasi Belajar Akuntansi Dasar (Y) akan meningkat sebesar 0,190 .

Berdasarkan Tabel 14 juga dapat dilihat harga-harga $F_{\text {hitung }}$ dan $F_{\text {tabel }}$ yang kemudian dibandingkan, kriteria yang digunakan adalah apabila $F_{\text {hitung }}$ lebih besar dari $F_{\text {tabel, maka hipotesis }}$ diterima, atau dengan kata lain variabel bebas (X) secara bersama-sama memberikan pengaruh positif terhadap variabel terikat $(\mathrm{Y})$. Dari perbandingan yang dilakukan, didapatkan hasil bahwa $F_{\text {hitung }}$ lebih besar dari $\mathrm{F}_{\text {tabel }}(7,398>$ 2,678), sehingga hipotesis diterima, atau terdapat pengaruh positif Motivasi Belajar, Persepsi Siswa tentang Metode Mengajar Guru, dan Perhatian Orang Tua secara bersama-sama terhadap Prestasi Belajar Akuntansi Dasar Siswa Kelas X Akuntansi dan Keuangan Lembaga SMK Negeri 1 Wonosari Tahun Ajaran 2018/2019.

Hasil tersebut didukung dari kajian teori, yaitu sesuai dengan pendapat yang diungkapkan Slameto
(2015:54-72) bahwa faktor-faktor yang dapat memengaruhi prestasi belajar beberapa diantaranya adalah motivasi, metode mengajar guru, serta keluarga dalam hal ini lebih khususnya perhatian orang tua. Siswa yang mendapatkan dan memiliki Motivasi Belajar yang tinggi akan berpengaruh pada kemampuan siswa dalam menerima pengetahuan dan pengalaman yang diberikan, sehingga pada akhirnya akan berpengaruh pula pada prestasi belajarnya yaitu Prestasi Belajar Akuntansi Dasar. Apabila Persepsi Siswa tentang Metode Mengajar Guru negatif maka akan menimbulkan tindakan-tindakan negatif pula seperti mengantuk, sulit menerima materi yang diberikan, bosan dan halhal lain yang menyebabkan hasil belajar yang kurang optimal. Begitu pula sebaliknya apabila Persepsi Siswa tentang Metode Mengajar Guru tersebut positif, maka hal ini kemungkinan akan membuat siswa bersemangat serta mudah dalam mengikuti dan menerima pembelajaran, sehingga akan menciptakan hasil berupa Prestasi Belajar Akuntansi Dasar yang optimal.

Perhatian Orang Tua juga memberikan pengaruh positif terhadap Prestasi Belajar Akuntansi Dasar. Siswa yang mendapatkan kasih sayang yang tulus dari orang tua tentu tidak akan merasa terkekang dalam proses belajarnya, perhatian dalam perkembangan proses belajar juga akan memberikan dorongan dan motivasi siswa untuk belajar serta meningkatkan Prestasi Belajar Akuntansi Dasar yang lebih baik, pemberian fasilitas belajar yang diperlukan siswa juga dapat meningkatkan prestasi belajar karena kebutuhan penunjang proses belajar dapat terpenuhi, serta lingkungan yang kondusif juga akan memengaruhi konsentrasi sehingga siswa dapat lebih nyaman dalam belajar, yang pada akhirnya akan berpengaruh pula pada Prestasi Belajar Akuntansi Dasar. 
Berdasarkan hasil penelitian yang diperoleh, menunjukkan bahwa semakin tinggi dan bagus Motivasi Belajar, Persepsi Siswa tentang Metode Mengajar Guru, dan Perhatian Orang Tua, maka akan semakin tinggi pula Prestasi Belajar Akuntansi Dasar yang diperoleh siswa.

\section{Sumbangan Reatif dan Sumbangan Efektif}

Tabel 15. Rangkuman Hasil Perhitungan Sumbangan Relatif dan Sumbangan Efektif

\begin{tabular}{|l|c|c|}
\hline \multirow{2}{*}{ Variabel } & \multicolumn{2}{|c|}{ Sumbangan } \\
\cline { 2 - 3 } & $\begin{array}{c}\text { Relatif } \\
(\%)\end{array}$ & $\begin{array}{c}\text { Efektif } \\
(\%)\end{array}$ \\
\hline $\begin{array}{l}\text { Motivasi Belajar } \\
\left(\mathrm{X}_{1}\right)\end{array}$ & 57,67 & 8,82 \\
\hline $\begin{array}{l}\text { Persepsi Siswa } \\
\text { tentang Metode } \\
\text { Mengajar Guru } \\
\left(\mathrm{X}_{2}\right)\end{array}$ & 12,23 & 1,87 \\
\hline $\begin{array}{l}\text { Perhatian Orang } \\
\text { Tua }\left(\mathrm{X}_{3}\right)\end{array}$ & 30,10 & 4,61 \\
\hline \multicolumn{1}{|c|}{ Total } & 100 & 15,30 \\
\hline
\end{tabular}

Berdasarkan hasil analisis dalam Tabel 15 dapat diketahui bahwa Motivasi Belajar memberikan Sumbangan Relatif sebesar 57,67\%, Persepsi Siswa tentang Metode Mengajar Guru sebesar 12,23\%, dan Perhatian Orang Tua sebesar 30,10\%. Sumbangan Efektif menunjukkan total sebesar $15,30 \%$, di mana masing-masing variabel memberikan Sumbangan Efektif yaitu Motivasi Belajar memberikan Sumbangan Efektif sebesar 8,82\%, Persepsi Siswa tentang Metode Mengajar Guru sebesar 1,87\%, dan Perhatian Orang Tua sebesar $4,61 \%$. Total tersebut menunjukkan bahwa Motivasi Belajar $\left(\mathrm{X}_{1}\right)$, Persepsi Siswa tentang Metode Mengajar Guru $\left(\mathrm{X}_{2}\right)$, dan Perhatian Orang Tua $\left(\mathrm{X}_{3}\right)$ secara bersama-sama memberikan pengaruh terhadap Prestasi Belajar Akuntansi Dasar Siswa Kelas X Akuntansi dan Keuangan Lembaga SMK
Negeri 1 Wonosari Tahun Ajaran 2018/2019 sebesar 15,30\%, dan masih ada sebesar 84,70\% faktor atau variabel lain yang tidak diteliti yang kemungkinan dapat memengaruhi Prestasi Belajar Akuntansi Dasar Siswa Kelas X Akuntansi dan Keuangan Lembaga SMK Negeri 1 Wonosari Tahun Ajaran $2018 / 2019$

\section{SIMPULAN DAN SARAN Simpulan}

Berdasarkan hasil penelitian dan pembahasan yang telah diuraikan pada bab sebelumnya, maka diperoleh kesimpulan sebagai berikut:

a. Terdapat pengaruh positif Motivasi Belajar terhadap Prestasi Belajar Akuntansi Dasar Siswa Kelas X Akuntansi dan Keuangan Lembaga SMK Negeri 1 Wonosari Tahun Ajaran 2018/2019 yang dibuktikan dengan koefisien korelasi yang bernilai positif yaitu $r_{x 1 y}=0,348$, koefisien determinasi $\left(\mathrm{r}_{\mathrm{x} 1 \mathrm{y}}^{2}\right)=0,114$, dan $\mathrm{t}_{\text {hitung }}>\mathrm{t}_{\text {tabel }}(4,012$ $>1,657)$.

b. Terdapat pengaruh positif Persepsi Siswa tentang Metode Mengajar Guru terhadap Prestasi Belajar Akuntansi Dasar Siswa Kelas X Akuntansi dan Keuangan Lembaga SMK Negeri 1 Wonosari Tahun Ajaran 2018/2019 yang dibuktikan dengan koefisien korelasi yang bernilai positif yaitu $\mathrm{r}_{\mathrm{x} 2 \mathrm{y}}=$ 0,275 , koefisien determinasi $\left(\mathrm{r}^{2} \mathrm{x} 2 \mathrm{y}\right)=$ 0,076 , dan $t_{\text {hitung }}>t_{\text {tabel }}(3,204>1,657)$.

c. Terdapat pengaruh positif Perhatian Orang Tua terhadap Prestasi Belajar Akuntansi Dasar Siswa Kelas X Akuntansi dan Keuangan Lembaga SMK Negeri 1 Wonosari Tahun Ajaran 2018/2019 yang dibuktikan dengan koefisien korelasi yang bernilai positif yaitu $r_{x 3 y}=0,254$, koefisien determinasi $\left(\mathrm{r}^{2} \times 3 \mathrm{y}\right)=0,064$, dan $\mathrm{t}_{\text {hitung }}>\mathrm{t}_{\text {tabel }}(2,301$ $>1,657)$.

d. Terdapat pengaruh positif Motivasi Belajar, Persepsi Siswa tentang Metode Mengajar Guru, dan Perhatian Orang 
Tua secara bersama-sama terhadap Prestasi Belajar Akuntansi Dasar Siswa Kelas X Akuntansi dan Keuangan Lembaga SMK Negeri 1 Wonosari Tahun Ajaran 2018/2019 yang dibuktikan dengan koefisien korelasi yaitu $\mathrm{R}_{\mathrm{y}(1,2,3)}$ bernilai positif sebesar 0,391 , koefisien determinasi $\left(\mathrm{R}^{2} \mathrm{y}(1,2,3)\right)$ sebesar 0,153 , dan $F_{\text {hitung }}>F_{\text {tabel }}(7,398$ $>$ 2,678). Sumbangan Relatif (SR) masing-masing variabel yaitu Motivasi Belajar sebesar 57,67\%, Persepsi Siswa tentang Metode Mengajar Guru sebesar $12,23 \%$, dan Perhatian Orang Tua sebesar 30,10\%. Sumbangan Efektif (SE) menunjukkan total sebesar $15,30 \%$, di mana masing-masing variabel memberikan Sumbangan Efektif yaitu Motivasi Belajar sebesar $8,82 \%$, Persepsi Siswa tentang Metode Mengajar Guru sebesar 1,87\%, dan Perhatian Orang Tua sebesar 4,61\%. Total tersebut menunjukkan bahwa Motivasi Belajar $\left(\mathrm{X}_{1}\right)$, Persepsi Siswa tentang Metode Mengajar Guru $\left(\mathrm{X}_{2}\right)$, dan Perhatian Orang Tua $\left(\mathrm{X}_{3}\right)$ secara bersama-sama memberikan pengaruh terhadap Prestasi Belajar Akuntansi Dasar Siswa Kelas X Akuntansi dan Keuangan Lembaga SMK Negeri 1 Wonosari Tahun Ajaran 2018/2019 sebesar $15,30 \%$, dan masih ada sebesar $84,70 \%$ kemungkinan dipengaruhi oleh faktor atau variabel lain selain ketiga variabel dalam penelitian ini.

\section{Saran}

Berdasarkan hasil penelitian yang diperoleh, maka peneliti dapat memberikan beberapa saran sebagai berikut:

a. Bagi Siswa

Disarankan siswa untuk dapat lebih disiplin dalam mengerjakan tugas yang diberikan oleh guru, belajar dengan giat dan lebih meningkatkan motivasinya serta memunculkan kesadaran pentingnya belajar, sehingga dapat memperoleh nilai yang lebih baik dalam ulangan akuntansi dasar. Siswa juga seharusnya dapat lebih aktif dalam pembelajaran akuntansi dasar hal ini dapat melatih percaya diri dan tentunya meningkatkan Prestasi Belajar Akuntansi Dasar.

b. Bagi Guru

Disarankan supaya guru lebih memelajari berbagai media pembelajaran yang menarik dan kreatif, hal ini dapat digunakan sebagai upaya untuk mendukung metode pembelajaran yang lebih variatif dan tidak monoton, guru juga sebaiknya sesekali memanfaatkan laboratorium yang ada di sekolah untuk menunjang kegiatan pembelajaran akuntansi dasar agar siswa juga mendapatkan suasana belajar yang beragam, tidak hanya selalu di dalam kelas.

c. Bagi Sekolah

Berdasarkan angket yang telah diisi siswa, tidak hanya guru yang berperan penting dalam meningkatkan Prestasi Belajar Akuntansi Dasar, pihak sekolah juga sebaiknya mendukung dengan memelihara dan mengelola fasilitas yang dimiliki oleh sekolah dengan baik. Sekolah juga sebaiknya lebih memperhatikan kompetensi guru yaitu dengan memberikan sosialisasi maupun pelatihan penggunaan media dan metode pembelajaran yang lebih baik dan variatif. Sekolah sebaiknya juga dapat membangun relasi yang lebih dekat dengan orang tua siswa dan dapat memberikan sosialisasi untuk menyadarkan pentingnya perhatian orang tua khususnya mendampingi anaknya dalam kegiatan belajar di rumah.

d. Bagi Peneliti

Penelitian ini memperoleh hasil bahwa Motivasi Belajar, Persepsi Siswa tentang Metode Mengajar Guru, dan Perhatian Orang Tua secara bersamasama memberikan pengaruh terhadap Prestasi Belajar Akuntansi Dasar Siswa Kelas X Akuntansi dan Keuangan Lembaga SMK Negeri 1 Wonosari 
Tahun Ajaran 2018/2019 hanya sebesar $15,30 \%$, dan masih ada sebesar $84,70 \%$ kemungkinan dipengaruhi oleh faktor atau variabel lain yang tidak diteliti dalam penelitian ini. Berdasarkan hasil tersebut peneliti menyarankan untuk penelitian selanjutnya dapat dilakukan penelitian mengenai faktor atau variabel lain yang tidak diteliti dalam penelitian ini untuk mengetahui faktor apa saja yang dapat memengaruhi Prestasi Belajar Akuntansi Dasar selain ketiga faktor atau variabel yang telah diteliti dalam penelitian ini.

\section{DAFTAR PUSTAKA}

Arikunto, S. (2013). Prosedur penelitian: suatu pendekatan praktik. Jakarta: Rineka Cipta.

Direktorat Jendral Pendidikan Dasar dan Menengah (2017). Kompetensi Keahlian Akuntansi dan Keuangan Lembaga SMK/MAK.

Faryadi, Q. (2017). Pedoman mengajar efektif: teori dan model pembelajaran. Bandung: Remaja Rosdakarya.

Fausi, M.R. (2017). Pengaruh Perhatian Orang Tua, Disiplin Belajar, dan Motivasi Belajar terhadap Prestasi Belajar Akuntansi Siswa Kelas XI IPS SMA Negeri 1 Depok Tahun Ajaran 2016/2017. Skripsi. Yogyakarta: UNY eprints.

Hadi, S. (2004). Analisis Regresi. Yogyakarta: Andi Offset.

Hadi, S. (2015). Metodologi Riset. Yogyakarta: Pustaka Pelajar Offset.

Irfa', A. (2017). Pengaruh Motivasi Belajar, Kreativitas Belajar, dan Lingkungan Teman Sebaya terhadap Prestasi Belajar Akuntansi Keuangan Siswa Kelas XI Akuntansi SMK Negeri 1
Tempel Tahun Ajaran 2016/2017.Skripsi. Yogyakarta: UNY eprints.

Khodijah, N. (2014). Psikologi Pendidikan. Jakarta: Rajagrafindo Persada.

Palupi, S.R. (2017). Pengaruh Kemandirian Belajar, Persepsi Siswa tentang Metode Mengajar Guru dan Perhatian Orang Tua terhadap Prestasi Belajar Akuntansi Siswa Kelas XI IPS SMA Negeri 1 Srandakan Tahun Ajaran 2016/2017. Skripsi. Yogyakarta: UNY eprints

Puspitasari, D. (2017). Akuntansi Dasar: program keahlian auntansi dan keuangan SMK/MAK. Jakarta: Bumi Aksara.

Sardiman. (2011). Interaksi dan Motivasi Belajar mengajar. Jakarta: Rajagrafindo Persada.

Siswoyo, D. (2013). Ilmu pendidikan. Yogyakarta: UNY Press.

Slameto. (2015). Belajar dan faktor-faktor yang memengaruhi. Jakarta: Rineka Cipta.

Slavin, R.E. (2011). Psikologi pendidikan: teori dan praktik. (Terjemahan Marianto Samosir). Jakarta: Indeks. (Edisi asli diterbitkan tahun 2009 oleh Pearson Education, Inc. New Jersey).

Sunyoto, D. (2011). Analisis regresi dan uji hipotesis. Yogyakarta: CAPS

Sugihartono. (2013). Psikologi pendidikan. Yogyakarta: UNY Press.

Sugiyono. (2016). Statistika untuk penelitian. Bandung: CV Alfabeta.

Surya, M. (2016). Psikologi guru: konsep dan aplikasi. Bandung: CV Alfabeta. 